\title{
RADON IN ALASKA: WHAT YOU SHOULD KNOW
}

Video download: doi.org/10.14509/30745

Video streaming: mediaspace.nau.edu/media/Alaska+Radon+Video/1_lk6hvklO

Authors: Mikaela R. Garcia, Raquel Goh, Mansel A. Nelson, Jennifer E. Athey, and Art L. Nash Jr.

\section{Suggested citation:}

Garcia, M.R., Goh, Raquel, Nelson, M.A., Athey, J.E., and Nash, A.L., Jr., 2021, Radon in Alaska: What you should know (video): Alaska Division of Geological \& Geophysical Surveys Information Circular 92, 2 p. https://doi.org/10.14509/30745

\section{Introduction}

Radon is a naturally occurring, radioactive gas estimated to be responsible for over 21,000 deaths in the U.S. per year. Radon is primarily associated with an increased risk of lung cancer and is the second leading cause of lung cancer after smoking. Because radon is colorless and odorless, testing for radon is the only way to find out if it is present in a building.

According to the Alaska Division of Public Health, radon is an under-recognized health risk in the state. Many homes tested throughout Alaska have radon levels above the Environmental Protection Agency's (EPA) limit of 4 picocuries per liter of air ( $\mathrm{pCi} / \mathrm{L})$. If a home or other building is found to contain radon, steps may be taken by the owner to reduce the concentration inside the structure.

The video "Radon in Alaska: What You Should Know" provides basic, introductory information about radon, how to test for this harmful gas, and mitigation techniques. Additional free resources about radon are available immediately below.

\section{Where can I go for more information about radon in Alaska?}

- Alaska Radon Hotline: 1-800-478-8324 (information about radon, testing, and mitigation)

- Online Alaska radon map: maps.dggs.alaska.gov/radon (interactive map of generalized radon test results and a radon predictive map for Alaska)

- Radon circular with general radon information: doi.org/10.14509/30163 (introductory radon information as double-sided flyer; print ready)

- Understanding your radon test: doi.org/10.14509/30467 (suggestions for next steps after testing and general information about mitigation techniques)

- Mitigating radon levels at home: doi.org/10.14509/30474 (do-it-yourself instructions for mitigating structures with radon concentrations greater than the EPA's action level)

- Alaska Division of Geological \& Geophysical Surveys (DGGS) radon website: dggs.alaska.gov/hazards/radon.html (general information and links to additional information)

- University of Alaska Fairbanks, Cooperative Extension Service (UAF-CES) website: www.uaf.edu/ces/foodhealth/radon/ (informational publications and videos)
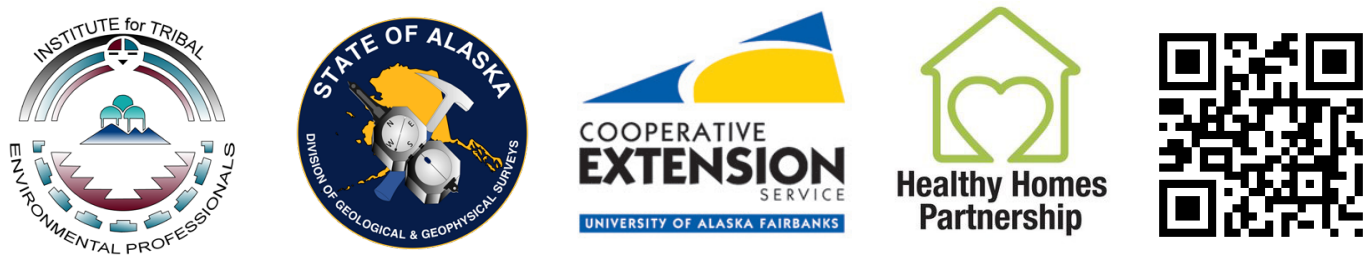


\section{Who is the intended audience of the video?}

The video was developed for rural Alaska and emphasizes building techniques, information, and imagery more commonly associated with rural dwellings, life, and available resources. The video also emphasizes imagery and information intended for Alaska Natives, as the majority of Alaska Natives live in small villages or remote regional hubs, most of which are located off of Alaska's road system. However, information in the video is applicable to the entire state and all residents.

\section{Why was the video created?}

Radon is an under-recognized health risk in Alaska, particularly in rural Alaska. Alaska's radon outreach program strives to educate Alaskans about radon as a hazard, and increase testing for radon, mitigation of homes with high radon concentrations, and radon-resistant new building construction. The ultimate goals of this program are to decrease lung cancer rates in Alaska and improve health outcomes for Alaskans.

The lack of available resources in rural Alaska, such as certified or experienced radon testing and mitigation service providers, and relatively long waits for mail services makes radon testing and mitigation very challenging in these areas. In addition, there are fewer opportunities for outreach and education in rural Alaska and those opportunities reach smaller numbers of residents and cost more to conduct. Creation and dissemination of this video is intended spark conversations about radon among rural residents and further the goals of Alaska's radon outreach program, which provides support and guidance on radon issues for all Alaskans.

\section{Who created the video and how was it funded?}

The video "Radon in Alaska: What You Should Know" was created by Northern Arizona University students Mikaela Garcia (editor) and Raquel Goh (script). Video content and editorial comments were provided by Mansel A. Nelson (Institute for Tribal Environmental Professionals [ITEP]), Jennifer E. Athey (DGGS), and Art L. Nash Jr. (UAF-CES).

Funding for the video was primarily provided to ITEP by the U.S. Environmental Protection Agency (EPA). Additional funding was provided by the EPA's FY21 State Indoor Radon Grant to the Alaska Department of Environmental Conservation, Division of Air Quality, titled "Alaska Air Quality Program and Radon Program", Award No. BG-96079706 (conducted by DGGS); UAF-CES Heathy Homes Partnership, Grant Award no. 2019-48540-30098; and State of Alaska General Funds.

For more information about this video and Alaska's radon outreach program, please contact Jennifer Athey at (907) 4515028 or jennifer.athey@alaska.gov.

\section{Acknowledgements}

We gratefully thank the following entities for video footage and stills: Village of Chickaloon, Village of Eklutna, Alaska Native Tribal Health Consortium (ANTHC; "Let's clear the air: Simple steps to a healthier home" [video]), UAF Cooperative Extension Service ("A Radon Overview" [video]), Kate Bull, Jeff Fay, Justin Freeman, Trystan Herriott, Jacquelyn Overbeck, James Roush, Evan Twelker, and DGGS staff.

Music was provided by the Athabascan Fiddlers Association recordings, featuring "Down River Boogie" by Ruby Combo, Billy McCarty Jr., Billy Savage, and Willy McCarty.

\section{Disclaimers}

Mention of trade names or commercial products does not constitute their endorsement by the Alaska Division of Geological \& Geophysical Surveys.

The State of Alaska makes no express or implied warranties (including warranties for merchantability and fitness) with respect to the character, functions, or capabilities of the electronic data or products or their appropriateness for any user's purposes. In no event will the State of Alaska be liable for any incidental, indirect, special, consequential, or other damages suffered by the user or any other person or entity whether from the use of the electronic services or products or any failure thereof or otherwise. In no event will the State of Alaska's liability to the Requestor or anyone else exceed the fee paid for the electronic service or product. 